REFLECTIONS:

NEUROLOGY AND THE

HUMANITIES

Section Editor

Anne W. McCammon,

MD, FAAN

\section{Floatopia, sarbox, and health care reform: The unintended consequences of law}

Lyell K. Jones, Jr., MD

Correspondence $\&$ reprint requests to Dr. Jones: lyell@mayo.edu
"Well, at least you look better in person than you do on paper," I told the septuagenarian sitting across the desk from me. "We've got that going for us."

My patient, a stoic semiretired farmer, offered a faint smile in half-hearted agreement. The pain in his legs, which I'm sure was killing him, kept him from taking too much reassurance from my observation.

But it was true. By my count he had no fewer than 12 active medical problems including the excruciating pain from his lower limb nerve damage, or peripheral neuropathy, resulting from his years of diabetes. $\mathrm{He}$ was on 14 daily medications, which fortunately had reached a tentative détente in their interactions with each other. He had survived 5 surgeries (1 performed emergently to revascularize his struggling heart several years ago), 2 motor vehicle accidents, and 1 tour of duty in Korea. Despite all of his medical problems, he hadn't missed a greatgrandchild's birthday yet, and he still helped his son and grandson at harvest time every fall.

Like many patients, most of his diagnoses were of the asymptomatic-until-catastrophe-strikes variety: high cholesterol, high blood pressure, a mediumsized and fortunately stable aneurysm in his belly. The neuropathy itself presented less of a risk to his health than his other medical problems. But I knew it bothered him more than anything else. The pain, particularly nagging at night, interfered with his sleep. He had stopped his daily walks with his wife because his feet hurt him so badly. A tall, narrow framed man, I could see his waistline had suffered as a result.

As his neurologist, I was working with his other physicians on strategies to control his neuropathic pain, and together we had failed miserably.

"So what's next?" he asked me. He had tried a number of medications over the years to mitigate the incessant burning and prickling in his feet and legs. The first medication had worked for a while, but had caused an abnormality in his heart rhythm ... that one had to go. Another drug interfered with the metabolism of his cholesterol medication, causing debilitating muscle pain for a while. A third never really got off the ground because it made him too dizzy. He kept a bar of soap in his bed for a few months and he was ready to swear by it, but even that eventually stopped working.

I sighed, scratched my chin, shifted in my seat, and thought: That's a really good question. What else can we do?

Floatopia. Perhaps strangely, public drunkenness in San Diego came to mind.

Increasing oceanside alcohol consumption by visitors to San Diego's beautiful city beaches has for many years been a concern of that city's leaders. The problem culminated in September 2007, when in the words of the subsequent city ordinance, "an alcohol-induced melee occurred in Pacific Beach," necessitating "San Diego police in riot gear to arrest sixteen people in order to restore the public peace." A prenoon ban on public alcohol consumption became a total ban, and by all accounts the sober sanctity of the beaches was restored.

That is, until Floatopia. Shortly after enactment of the policy, a loophole was discovered: while clearly banning alcohol consumption on beaches, parks, and other city right-of-ways, the city ordinance had specifically neglected to mention drinking while in the water. Erstwhile beachdrinkers, now armed with plastic floats in addition to their coolers, organized huge float parties in the shallow beachside bays. These Floatopias grew in popularity, frequency, and size; by 2010, several thousand inebriated souls might be found bobbing on flimsy inflatable rafts in the Saturday afternoon sun.

Aside from the obvious safety risks associated with mass drunkenness afloat, this unintended consequence of the beach alcohol ban was costing the city thousands of dollars in lifeguard and police overtime (fortunately, there were no reported drownings). The mountains of alcohol-themed jetsam washing up on the teetotaling sand weren't particularly attractive either. Eventually, the oversight in the law was closed in the summer of 2010 with a measure passed by the city council.
Supplemental data at www.neurology.org
Listen to Dr. Jones read this story (audio file on www.neurology.org). Beginning with the March 27 issue, this feature will be available exclusively on the Neurology ${ }^{\circledR}$ app for the iPad.

Certain biographical features have been altered to protect patient confidentiality. 
I didn't discuss Floatopia with my patient. Cleareyed with a close-cropped fringe of gray hair, he had a good sense of humor and would have appreciated the analogy I think. But he had experienced firsthand the law of unintended consequences in those reactions to his prior medications. And while these adverse effects had been unintended, they certainly weren't entirely unexpected. They were all common side effects that we'd discussed before each trial, weighing the risks and benefits of each option.

We had in a sense already discussed unexpected outcomes. Many of the medications we had tried for his pain, in fact, were initially developed to treat other problems and had serendipitously been found to help some patients with neuropathic pain (an example of the uncommon positive unintended consequence). The medication that interfered with his cardiac rhythm has been used for decades to treat depression. The drug that made him dizzy is an antiepileptic, but is widely recognized as a good treatment for neuropathic pain. Advantageous but initially unanticipated benefits in fact describe the majority of the drugs we use to treat chronically painful neuropathies.

There is a certain reassurance in cause and effect. Robert Merton, ${ }^{1}$ in his 1936 article "The unanticipated consequences of purposive social action," defined the concept of unanticipated consequences and identified the need to understand the role of "causal imputation" in the genesis of those outcomes. Reassuringly, with many medical interventions, unwanted results can be eliminated with removal of the therapy. This pill makes you too sleepy? Let's try something else. That one makes blood squirt out of your ears? Well, let's just go ahead and stop that one.

But as we had systematically tried, and failed, with the medications I thought would be most likely to help him, my patient and I were left with a thinning crop of options. What if there's just nothing else that could work for him? Or what if I start a drug that has a marginal benefit now, but results in an unforeseen disaster far down the road?

Sarbox. If a rising tide lifts all floats, an ebbing tide lets you know which may not have been seaworthy to begin with.

In 2001, as the US economy sank into recession and the bubble in technology stocks was popping, a number of companies went out of business. Some of these failures could be attributed to secular changes in the market and the economy, but it became clear that many corporations had been misrepresenting their prior financial health. Some had artificially transferred their liabilities to shadow corporations, masking their own insolvency. Others fabricated assets that did not exist. Investors were fleeced, the names Enron and Worldcom became synonymous with "accounting scandal," and policymakers responded vigorously.

To protect shareholders and galvanize regulators, a number of arcanely titled policies were enacted. The Sarbanes-Oxley Act of 2002 and Financial Accounting Standard Number 157 in 2006 set new standards for accounting transparency by publicly held companies. While there was grumbling from the business community about the costs of compliance with these new regulations, particularly with Sarbanes-Oxley or "Sarbox," the good intentions were clear.

Several years later, as the next recession and global financial crisis unfolded in 2008, a problem with these regulations emerged. Nested within the new policies was a general obligation to "mark-tomarket," a requirement for companies to transparently value their assets according to current worth rather than artificially inflating them according to an optimistic future value. As capital markets plunged in value, from the housing market to the stock market, companies were compelled to record and report assets according to spiraling crisis valuations, further accelerating the decline and inflaming the panic. Although noble in purpose, the new regulations had been based on an assumption of well-functioning, liquid capital markets. This unanticipated and epochal freezing of markets, thoroughly outlined in the 2011 report from the Financial Crisis Inquiry Commission, exposed the flaws of otherwise well-intentioned policies. Eventually, after the crest of the panic had passed, the mark-to-market requirements were relaxed in 2009 for certain illiquid market conditions.

Economists, the grim purveyors of the dismal science, are perhaps the most attuned to the concept of unintended consequences. Steven Levitt, the economist of Freakonomics fame, has described numerous examples in his scholarly work, and other examples abound in the arena of public policy. Economists Daron Acemoglu and Joshua Angrist, ${ }^{2}$ in their 2001 paper "Consequences of employment protection? The case of the Americans with Disabilities Act," noted a counterintuitive drop in employment among disabled men and women following the enactment of the Americans with Disabilities Act in 1992. The Act was intended to correct years of ingrained employment discrimination against disabled workers, and though it was ultimately successful in doing so, it initially had the opposite effect. This has since been attributed to employers' anxiety over compliance with the new regulations, resulting in lower hiring rates among the disabled, an outcome that was the opposite of the intent of the law.

Health care reform. My patient and I had never talked about the ongoing national health care reform 
discussion, but other patients have asked me what I think will happen with it. Rather than delve into a polarizing topic, I tell them which principles are important to me, such as preserving patient access to care, maximizing the value of the care we provide, fostering clinical teamwork, and improving communication between physicians and patients.

And really, how could I pretend to tell them what will happen? Intervention in any complex system, be it biological, economic, or legal, introduces the risk of unexpected outcomes. What is perhaps more important is the reaction to those consequences. Floatopia was resolved with the stroke of a pen, and financial regulations in response to the recent economic crisis have been adjusted, with nearly immediate effect.

What will be the case with the recent health care law? The hundreds of pages that comprise 2010s Patient Protection and Affordable Care Act contain directives that make sweeping changes in the provision of health care in the United States. Some unintended consequences of the law have in fact already been encountered, and to an extent addressed. In September 2010, Anthem Blue Cross, Aetna, and other insurers announced they would stop offering childonly policies in a number of states to avoid the new preexisting condition requirement, effectively reducing available coverage for those children who could not be covered in a family plan. California enacted legislation in early 2011 that would exclude these companies from the broader insurance market unless they provide this coverage, and as a result most of these companies have retracted the change.

What other unintended consequences of health care reform lie in wait? There has been widely publicized concern that an unintended result of the pending ban on denial of coverage for preexisting conditions will be an increase in the costs of coverage, as those who are healthy may opt to pay a fine and obtain their coverage "just in time" if they get sick. This could be a particular problem if the individual mandate to purchase coverage does not survive its ongoing legal challenges.
While fear of unanticipated outcomes should not serve as an excuse for inaction, particularly in a time of crisis, it should prompt us to consider possible unwanted results. The reform law itself takes into account some of the potential for unanticipated consequences with a number of pilot projects. But unlike regulation in other arenas, the results of this law on the ultimate product of our health care economy (i.e., the health of our population) may not be fully known for a generation or more. And as these and countless other examples of the law of unintended consequences demonstrate: surprises are unavoidable. What matters is how quickly and how well we are able to respond to them.

The plan. My patient and I chatted for a while about our options. A thoughtful man, the decision to try another drug was ultimately his after I presented him the options, each with its own risks and benefits. Eventually, he decided to try a new medicine for his progressive pain.

"So this one might make me irritable?" he asked.

"Yes," I said.

"And what was the other thing?" he asked.

"It might make you sweat excessively," I answered. He chuckled again.

"And if it does?"

"Well, give me a call and we might stop it, look for something else," I said. I repeated that there might be side effects we can't predict, and that if he has them the important thing to do is let me know so we can act accordingly.

We shook hands, and I didn't hear from him for a while. He ended up tolerating the medication just fine, but it didn't really help his pain. We're still working on that.

\section{REFERENCES}

1. Merton RK. The unanticipated consequences of purposive social action. Am Sociol Rev 1936;1:894-904.

2. Acemoglu D, Angrist J. Consequences of employment protection? The case of the Americans with Disabilities Act. J Political Economy 2001;109:915-957. 


\section{Neurology}

Floatopia, sarbox, and health care reform: The unintended consequences of law Lyell K. Jones, Jr.

Neurology 2012;78; $20-\mathrm{e} 22$

DOI 10.1212/WNL.0b013e3182436576

\section{This information is current as of January 23, 2012}

\section{Updated Information \&} Services

\section{Supplementary Material}

\section{References}

Subspecialty Collections

Permissions \& Licensing

Reprints including high resolution figures, can be found at: http://n.neurology.org/content/78/4/e20.full

Supplementary material can be found at: http://n.neurology.org/content/suppl/2012/01/22/78.4.e20.DC1

This article cites 2 articles, 0 of which you can access for free at: http://n.neurology.org/content/78/4/e20.full\#ref-list-1

This article, along with others on similar topics, appears in the following collection(s):

\section{Medical care}

http://n.neurology.org/cgi/collection/medical_care

Information about reproducing this article in parts (figures,tables) or in its entirety can be found online at:

http://www.neurology.org/about/about_the_journal\#permissions

Information about ordering reprints can be found online:

http://n.neurology.org/subscribers/advertise

Neurology ${ }^{\circledR}$ is the official journal of the American Academy of Neurology. Published continuously since 1951, it is now a weekly with 48 issues per year. Copyright Copyright $@ 2012$ by AAN Enterprises, Inc.. All rights reserved. Print ISSN: 0028-3878. Online ISSN: 1526-632X.

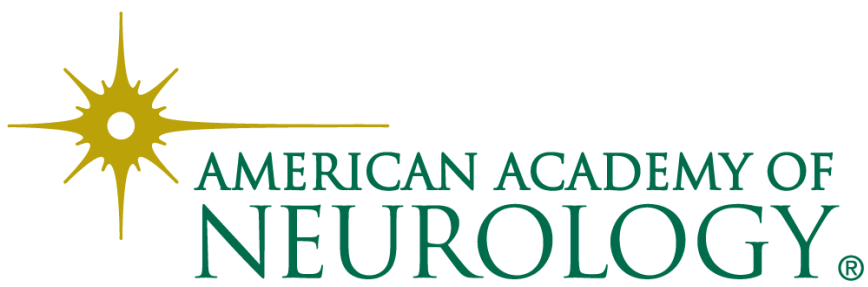

